\title{
How improvisation techniques can support researchers with the development of public speaking skills
}

\section{Nicola Grayson}

University of Manchester

Jessica Napthine-Hodgkinson

University of Manchester

\section{Abstract}

Through the presentation of a workshop entitled 'Enhancing public speaking skills using improvisation techniques' this case study will argue that improvisational techniques can disrupt the seriousness of researcher development training to release stress and provide a cathartic space for researchers to develop skills and support one another. The landscape of researcher support is traditionally a serious terrain, and the impacts of the pressures faced by researchers are well documented (Evans et al., 2018). Opportunities for researchers to work together and support one another are relatively rare, yet research has shown that peer-topeer support benefits them immensely (Boud and Lee, 2007). In 2018, the University of Manchester Library reviewed its researcher development programme and adopted a new approach that emphasises the value of researchers working in a community with peers both within and outside of their subject area. The workshop exemplifies this approach, as it encourages researchers to support one another to develop public speaking skills in a way that is innovative, fun and enjoyable. Attendees work together in a space where the freedom to fail offers them a cathartic release from the pressures of perfection. As a result, researchers can reframe their worries into opportunities to connect with one another and grow and this empowers them to build confidence in their ability to engage with others in dialogue about their research. 
Keywords: researcher development; improvisation; fun, public speaking; anxiety; community; playful learning.

\section{Introduction}

'I got my actors to make faces, insult each other, always to leap before they looked, to scream and shout and misbehave in all sorts of ingenious ways... In normal education everything is designed to suppress spontaneity, but I wanted to develop it' (Johnstone, 1979).

The spirit of disruptive spontaneity is key to what makes improvisation such a powerful tool for helping researchers overcome their anxiety about public speaking. Improvisation exercises reframe failure not as something to be ashamed of, but as an opportunity to learn and grow. This reframing of failure is gaining momentum in the sphere of researcher development (see Whitnall and Hurley, 2019), but it is still a relatively new approach.

For the same reason that we all struggle with public speaking, researchers report feelings of anxiety and dread when faced with the prospect of presenting their work to others at conferences or events. Yet it is crucial for researchers to gain feedback and justify their work before seeking to publish; it is a necessary (and very useful) part of the research process. The fear of being asked a question that they cannot answer in front of their peers and the embarrassment at the physiological reactions to nerves (such as blushing, stumbling over words or struggling for correct academic phrasing) are all common worries attached to the prospect of public speaking which can be a barrier to career and research progression. Members of the research community are also particularly prone to the psychological phenomenon referred to as 'imposter syndrome' - feelings of inadequacy that persist despite evidence of success (Kearns, 2015). Add this to anxiety about public speaking, and the barriers increase; the risk is that when opportunities arise for researchers to share their ideas and gain valuable feedback, nerves may prevent them from fully participating in, and benefiting from, these experiences. Anxiety about public speaking also leads to increased self-awareness, and this can seriously hamper individuals from connecting with their audiences (Daly et al., 1989). 
Researcher development support for presentation skills at the University of Manchester (UoM) has traditionally focused on structuring work effectively, practising the presentation and projecting the voice. These are all things that individuals are expected to work on by themselves in order to create a good impression and avoid making mistakes. In the newly developed workshop entitled 'Enhancing public speaking skills using improvisation techniques', actions which could lead to 'mistakes' in another context are instead presented as opportunities for growth, as researchers work together to support one another to reenvisage the presentation as a dialogue. In doing this, the hierarchy of responsibility for speaking becomes levelled, the power dynamic is adjusted, and 'presenters' must reframe their interaction with the audience as a creative 'back and forth' rather than one-way communication in which they receive nothing in return. Public speaking itself is thereby also reframed as a dialogue between presenter and audience, which helps to combat the fear of being judged. In a one-way 'presentation' the presenter is vulnerable to critique from the audience, but in a two-way 'dialogue', both parties contribute to shaping discussion; responsibility is thereby released and the presenter becomes an equal party in the exchange rather than one who is subject to critique and scrutiny. The reframing means that the prospect of public speaking no longer induces such fear, it is instead an opportunity for a new and rewarding experience in which speakers can enrich their ideas in order to move forward in their research (see Dweck, 2008 on the value of a growth mind-set approach to learning).

There is little evidence to date on the value of using improvisational techniques in order to release stress, encourage fun and enable researchers to work on practical skills in a community with others to benefit their personal and professional development. In order to contribute to this area, we have sought to document the work we have undertaken at the UoM Library, in the hope that those who desire to adopt such techniques in their own work should experience the same positive responses.

\section{Context: the guiding principles which shape our programme of support}

The workshop 'enhancing public speaking skills using improvisation techniques' is part of the UoM Library's My Research Essentials (MRE) researcher development programme. MRE is a 
blended offer of support which includes open online resources, 'open to all' face-to-face workshops and events, and a 'bespoke' programme of support requested by specific schools, departments or faculties. The core audience for MRE are postgraduate researchers (PGRs), who comprise $72 \%$ of our audience, research and university staff, who comprise $25 \%$, and a small number of postgraduate taught (master's) students (3\%). The researcher population at the UoM is approximately 6,000, with around 2,000 research staff and, on average, around 4,000 postgraduate researchers each year. The MRE programme was subject to review in 2018; the Library wanted to build on some of the pedagogical and evaluation expertise developed through coordination of its undergraduate-focused programme, My Learning Essentials (MLE), for MRE in order to ensure quality and to promote best practice (see Blake et al., 2019 on the impact of MLE on student attainment).

In summary, the changes made to MRE involved expanding the range of support on offer whilst also aligning with the work done centrally at the UoM as part of an OfS funded PGR Mental Health and Wellbeing Project. A new set of principles was agreed by all key stakeholders (within the Library and the university wide Researcher Development Group, which comprises representatives from each of the faculties, careers and staff learning development), to guide the creation of a new content for MRE. The principles are as follows:

- Is there a demonstrated need for this support? The need can be identified by researchers themselves or by the university, for example, with respect to policy requirements such as REF (Research Excellence Framework) eligibility.

- Is the Library the best place to deliver or host this support? If the support clearly falls under the remit of one of the faculties, then the answer is 'no', but if it relates to an area that would benefit from being open to all, then the MRE team can consider it.

- Is support delivered in a way that is inclusive and accessible? This is a quality assurance measure to ensure equality of access to support and resources for all UoM researchers.

- Is the delivery of this support sustainable? From a resource point of view, can the Library deliver or sustain the support?

- Does the delivery of support promote a sense of community amongst researchers? It is this addition to the MRE approach which constitutes the biggest 
shift in focus for the programme. In order to address some of the well-documented difficulties that PGRs and research staff face (particularly in relation to mental health and wellbeing (see Evans et al., 2018), this question is designed to ensure that MRE support makes the most of any opportunities to enhance the researcher experience. It recognises the value and power of community as a tool to combat isolation, and its inclusion means that any new content must include provision for researchers to support one another, work together and share experiences to move the UoM's research culture forwards in a positive way.

A review of MRE attendee feedback from the academic year 2018/2019 revealed that researchers were asking for more support in areas such as academic writing, presentation skills and coping with stress. The public speaking workshop was one of the ways in which the Library responded to these requests. It was piloted as a masterclass in communication skills for the postgraduate researcher representatives (PGR reps) in summer 2019 before becoming a part of our regular programme of events. The goal in trialling this workshop with the reps was to address the fear and anxiety they reported about speaking up for their peers at committees and meetings which contained senior members of staff. The reps (many of whom were from minority groups which are underrepresented at the university) reported feeling very nervous about the prospect of speaking up in meetings. They felt intimidated by the seniority of some staff members and reported that they would 'freeze up' and not contribute ideas, even if they had them. The objective was to try a different approach to public speaking, which acknowledged the fear that is attached to this activity. The workshop provided attendees with techniques to embrace spontaneity and encouraged them to participate in activities which required them to 'reframe' what they perceived as 'serious high stakes situations' into 'positive opportunities' to add to and build upon the ideas of others.

The pilot workshop was well received and became part of MRE's regular programme of events. In response to the feedback gathered, it has evolved through a series of iterations; attendees asked for more time to practise the skills covered and for more support with networking skills, so this was built into the session (See Hattie and Timperley, 2007 on the importance of responding effectively to feedback). A workshop was also scheduled before the university's annual PGR Summer Showcase (where researchers can present posters and 
practise explaining their research to 'judges' and attendees with the chance to win prizes) in order to ensure that support was clearly anchored to the practical challenges faced by the MRE audience.

The MRE programme is led by a Learning Developer (with a background in theoretical philosophy) who worked with the Library's Teaching and Learning team to devise the guiding principles which inform the MRE programme's content. The team used their experience of design, delivery, coordination and evaluation of support to inform the review of MRE and to implement changes. The Enhancing Public Speaking Skills... workshop was developed and delivered by a member of Library staff who is also an experienced improvisation facilitator; she has previously used improvisation techniques to create and deliver confidence-building workshops in community settings, and for the Association of University Administrators.

The facilitator developed the session to ensure that any opportunities for peer-to-peer interaction and support were utilised in line with MRE's new emphasis on the importance and value of community. The partnership resulted in a fortuitous merging of expertise in relation to improvisation techniques (with a particular focus on authenticity in delivery), philosophy (and the use of approaches advocated by, for example, Simone De Beauvoir, in relation to combating imposter syndrome; see De Beauvoir, 1963) and pedagogical approaches familiar to the field of learning development, which include, but are not limited to:

- Using feedback to effect change (see Hattie and Timperley, 2007).

- Using facilitation to empower learning (see Blake and Illingworth, 2015 for how this has been successfully implemented at the UoM).

- Peer mentoring and the use of peer support (see Andrews and Clark, 2011 on the value of this).

- The use of a 'release of responsibility model' in workshops across the programme (when possible) to enable attendees to take ownership of, and responsibility for, their own learning (see Fisher and Frey, 2013 on this approach). 


\section{Methods: key themes, goals and objectives behind the techniques}

The key objectives that the Enhancing public speaking skills using improvisation techniques workshop was designed to address are set out below:

- Preparation for public speaking.

- Developing a positive attitude.

- Connecting with an audience or peers.

- Becoming more concise in speech.

- Showing passion and enthusiasm.

- Embracing failure as an opportunity for growth.

The objectives communicate the goals of using the improvisational techniques, and Table 1 below sets out the exercises used, each objective they relate to, how they are conducted, and the benefits they have in supporting attendees with the development of public speaking skills.

Table 1. The improvisational exercises used and their objectives.

\begin{tabular}{|l|l|l|l|}
\hline Exercise & Objective & Outline & Benefit \\
\hline $\begin{array}{l}\text { Warm up: } \\
\text { lemon } \\
\text { face, } \\
\text { pumpkin } \\
\text { face }\end{array}$ & $\begin{array}{l}\text { Preparation } \\
\text { for public } \\
\text { speaking }\end{array}$ & $\begin{array}{l}\text { Contraction of facial muscles } \\
\text { into the face that would be } \\
\text { pulled when biting into a sour } \\
\text { lemon followed by stretching of } \\
\text { muscles into a wide, open face } \\
\text { akin to a carved pumpkin. }\end{array}$ & $\begin{array}{l}\text { Alternating quickly between the } \\
\text { two faces warms up the facial } \\
\text { muscles and helps attendees } \\
\text { to prepare for speech. It also } \\
\text { makes attendees laugh and } \\
\text { acts as an icebreaker to set a } \\
\text { playful tone for further } \\
\text { interactions }\end{array}$ \\
\hline $\begin{array}{l}\text { Warm up: } \\
\text { breathing } \\
\text { exercise }\end{array}$ & $\begin{array}{l}\text { Preparation } \\
\text { for public } \\
\text { speaking }\end{array}$ & $\begin{array}{l}\text { Guided breathing in for the } \\
\text { count of four, holding the breath } \\
\text { for the count of four, then } \\
\text { exhaling for the count of four. }\end{array}$ & $\begin{array}{l}\text { Attendees experience the } \\
\text { calming effects of deep } \\
\text { breathing and are encouraged } \\
\text { to do this when they are feeling } \\
\text { nervous. }\end{array}$ \\
\hline $\begin{array}{l}\text { Warm up: } \\
\text { vocal } \\
\text { exercises }\end{array}$ & $\begin{array}{l}\text { Preparation } \\
\text { for public } \\
\text { speaking }\end{array}$ & $\begin{array}{l}\text { A theatrical, exaggerated yawn, } \\
\text { making a loud, short 'ha' sound, } \\
\text { thinking about the noise } \\
\text { originating in the abdomen and } \\
\text { pushing up out of the mouth. }\end{array}$ & $\begin{array}{l}\text { Yawning helps to lower the } \\
\text { larynx and relieve tension } \\
\text { around the throat, which in turn } \\
\text { allows the production of a } \\
\text { richer, more resonant voice } \\
\text { (Boone and MacFarlane, }\end{array}$ \\
\hline
\end{tabular}




\begin{tabular}{|c|c|c|c|}
\hline & & & $\begin{array}{l}\text { 1993). The 'ha' exercise } \\
\text { encourages movement of the } \\
\text { diaphragm to support vocal } \\
\text { production to make the voice } \\
\text { stronger and more } \\
\text { commanding. }\end{array}$ \\
\hline $\begin{array}{l}\text { Warm up: } \\
\text { mental } \\
\text { agility } \\
\text { exercises }\end{array}$ & $\begin{array}{l}\text { Preparation } \\
\text { for public } \\
\text { speaking } \\
\text { Embracing } \\
\text { failure }\end{array}$ & $\begin{array}{l}\text { Naming the days of the week in } \\
\text { order going around the table. } \\
\text { Then following the same pattern } \\
\text { but with the order of the days } \\
\text { reversed. }\end{array}$ & $\begin{array}{l}\text { This encourages attendees to } \\
\text { disrupt their usual thinking } \\
\text { patterns, which makes them } \\
\text { more responsive to others. The } \\
\text { pattern goes wrong as it gets } \\
\text { more complex, but this makes } \\
\text { attendees laugh and helps } \\
\text { them to embrace failure. }\end{array}$ \\
\hline $\begin{array}{l}\text { Yes but... } \\
\text { yes and }\end{array}$ & $\begin{array}{l}\text { Developing } \\
\text { a positive } \\
\text { attitude }\end{array}$ & $\begin{array}{l}\text { In groups, attendees plan an } \\
\text { event as chosen by the group, } \\
\text { e.g. a wedding. Each time an } \\
\text { attendee offers a suggestion, } \\
\text { another attendee must counter } \\
\text { with a reason why that will not } \\
\text { work. } \\
\text { The planning then continues but } \\
\text { instead of rejecting ideas, } \\
\text { attendees are encouraged to } \\
\text { accept and add to each } \\
\text { suggestion. }\end{array}$ & $\begin{array}{l}\text { Repeated negative responses } \\
\text { mean that no ideas are } \\
\text { developed and therefore } \\
\text { planning is stunted, which feels } \\
\text { frustrating, but then the } \\
\text { exercise focuses on accepting } \\
\text { and adding to suggestions, } \\
\text { which fosters a positive and } \\
\text { collaborative mindset. It } \\
\text { reframes public speaking as an } \\
\text { opportunity to discuss ideas. }\end{array}$ \\
\hline $\begin{array}{l}\text { Make your } \\
\text { garden } \\
\text { grow }\end{array}$ & $\begin{array}{l}\text { Connecting } \\
\text { with an } \\
\text { audience or } \\
\text { peers }\end{array}$ & $\begin{array}{l}\text { A volunteer is invited to take on } \\
\text { the role of the sun, everyone } \\
\text { else is asked to be a flower in } \\
\text { their garden. The sun has to } \\
\text { speak for one minute on any } \\
\text { topic and during this time, they } \\
\text { have to make eye contact with } \\
\text { all of the flowers in their garden. } \\
\text { lf the sun is shining on them the } \\
\text { flowers must 'bloom' (by } \\
\text { spreading their hands, arms or } \\
\text { even standing up), conversely, if } \\
\text { there is no eye contact, they } \\
\text { must start to wither and shrink in } \\
\text { their seats. }\end{array}$ & $\begin{array}{l}\text { 'Gamifying' something one } \\
\text { finds uncomfortable may help } \\
\text { to make it less daunting } \\
\text { (Fleming et al. 2017). It gives } \\
\text { attendees the chance to } \\
\text { practise making eye contact to } \\
\text { help them feel more } \\
\text { comfortable when presenting } \\
\text { or networking. }\end{array}$ \\
\hline $\begin{array}{l}\text { Say more } \\
\text { with less }\end{array}$ & $\begin{array}{l}\text { Becoming } \\
\text { more } \\
\text { concise with } \\
\text { speech }\end{array}$ & $\begin{array}{l}\text { In their own time, attendees can } \\
\text { practise a section of their } \\
\text { presentation that is five minutes } \\
\text { in length, then they rework it to } \\
\text { fit into three minutes, then again } \\
\text { into one minute, then } 30\end{array}$ & $\begin{array}{l}\text { This helps attendees to identify } \\
\text { the key points they want to } \\
\text { make, so they can adapt their } \\
\text { presentation to focus on the } \\
\text { core messages. It helps to } \\
\text { make a speech more dynamic }\end{array}$ \\
\hline
\end{tabular}




\begin{tabular}{|c|c|c|c|}
\hline & & $\begin{array}{l}\text { seconds, then } 10 \text { seconds. Try } \\
\text { not to speed up delivery - the } \\
\text { final round should just have key } \\
\text { words. }\end{array}$ & and less like a script. \\
\hline $\begin{array}{l}\text { Networkin } \\
\text { g exercise }\end{array}$ & $\begin{array}{l}\text { Connecting } \\
\text { with an } \\
\text { audience or } \\
\text { peers }\end{array}$ & $\begin{array}{l}\text { During the halfway refreshment } \\
\text { break attendees are set a } \\
\text { variety of challenges, for } \\
\text { example: } \\
\text { - Beat three other people in } \\
\text { Rock, Paper, Scissors. } \\
\text { - Find two people with a } \\
\text { sporty hobby. Why do they } \\
\text { love it? } \\
\text { - Find someone with a } \\
\text { different star sign to you and } \\
\text { look at today's horoscope - } \\
\text { is it accurate? }\end{array}$ & $\begin{array}{l}\text { Attendees practice networking } \\
\text { in a comfortable, accepting } \\
\text { environment. The 'challenges' } \\
\text { allow them to focus on a task } \\
\text { rather than any feelings of } \\
\text { anxiety. }\end{array}$ \\
\hline $\begin{array}{l}\text { Commit to } \\
\text { the bit }\end{array}$ & $\begin{array}{l}\text { Showing } \\
\text { passion and } \\
\text { enthusiasm }\end{array}$ & $\begin{array}{l}\text { In their own time attendees can: } \\
\text { - Practise the speech and try } \\
\text { varying the pace or volume } \\
\text { of their voice. } \\
\text { - Try delivering it with different } \\
\text { emotional expressions, for } \\
\text { example, excited, serious, as } \\
\text { if confiding in someone. } \\
\text { - Try a different style, for } \\
\text { example, Shakespearean, } \\
\text { gangster, musical. }\end{array}$ & $\begin{array}{l}\text { These techniques help } \\
\text { attendees to cultivate their own } \\
\text { authentic style of delivery. } \\
\text { Repetition will also better equip } \\
\text { attendees to remember their } \\
\text { speech without it becoming } \\
\text { stale as they become } \\
\text { accustomed to constantly } \\
\text { adapting and refining it. }\end{array}$ \\
\hline $\begin{array}{l}\text { Your time } \\
\text { to shine }\end{array}$ & $\begin{array}{l}\text { Connecting } \\
\text { with an } \\
\text { audience or } \\
\text { peers. } \\
\text { Showing } \\
\text { passion and } \\
\text { enthusiasm }\end{array}$ & $\begin{array}{l}\text { Each attendee is given an } \\
\text { unusual topic such as 'pickles } \\
\text { from around the world' or 'the } \\
\text { possibility of unicorns'. They are } \\
\text { then invited to deliver a one- } \\
\text { minute talk, and the audience } \\
\text { applauds each talk. }\end{array}$ & $\begin{array}{l}\text { This allows attendees to take } \\
\text { an important step in their public } \\
\text { speaking journey. It } \\
\text { demonstrates to the speaker } \\
\text { that they are capable of } \\
\text { engaging an audience and } \\
\text { creates a positive experience } \\
\text { of public speaking for them to } \\
\text { build on in future. }\end{array}$ \\
\hline
\end{tabular}

Underlying the objectives outlined above, there are some key themes of improvisation, which also informed the way that the workshop was designed and delivered. These are explained below. 


\section{Emphasising the power of positivity and playfulness}

The 'Yes and' approach disrupts negative thought patterns by encouraging an initial response of acceptance rather than rejection, and thereby prompts attendees to build on an idea in a positive way. Lisa M. Barker notes in the findings of her 2017 study that her subject, a teacher who had undertaken a 10-week improvisation course, found that the 'Yes and...' tenet had a positive impact on how he engaged in discussion with students. He mentions a dynamic feeling of 'flow' as the dialogue moves back and forth, and each respondent feels compelled to acknowledge and build upon the other's contributions in a symbiotic way. When reframed in this way, public speaking becomes transposed from a daunting prospect, in which the speaker has to face a sea of strangers perceived as waiting to judge them, to an opportunity to offer up ideas to spark further discussion, as others are given a chance to contribute. In this vein, questions from the audience are no longer received as potential criticisms; they are accepted as further opportunities to build upon the foundation created by the speaker. This allows for a more dialogic experience and a greater exploration of the topic being discussed. Throughout the workshops, attendees were encouraged to share their own experiences and to ask questions to cement their experience of public speaking as comprising elements of give and take rather than being monologic.

In Process: an improviser's journey, Mary Scruggs writes about her experience of improvisation and its playful approach: 'The games I learned laid a foundation of playfulness, creativity, spontaneity and connection to others' (Scruggs and Gellman, 2008). The playful aspect of improvisation encourages attendees to engage with one another and to be more 'present' in the exercises covered during the session. The intention behind modelling this experience within the session is that attendees will be able to recreate those feelings of connection and playfulness (Nørgård, et al., 2017) in their future work.

\section{Connecting authentically in a safe space}

Improvisation exercises provide a safe space for a prospective presenter to try out speaking to an audience to make the most of the chance to connect when the opportunity to present their work arises. As long-running improvisation company, The Second City, puts it: 'Improv classes are a great way to gain confidence and feel more comfortable speaking to a group of 
people. After all, your fellow members are in the same boat as you, so you don't have to worry about feeling silly or scared of failure' (The Second City, 2020).

Feeling safe and comfortable speaking to an audience comes with experience, and each public speaking activity chips away at the feelings of apprehension and anxiety about the unknown. Attendees moved from speaking in small groups in a structured exercise, through one-on-one networking challenges, to finally delivering a speech to an audience of their peers. Rubin et al. (1997) found that students who participated in a communication course perceived their levels of 'communication apprehension' to be significantly lower by the end of the course. When speakers are able to make a connection, they can see that their audience is engaged in listening to them and the feelings of anxiety start to dissipate. The reassurance this brings can help speakers to relax; they are less likely to look and sound tense, and in turn the way that they conduct themselves is more appealing to an audience, as they can express themselves more fully through their voice and body language.

Authenticity is a key element of improvisation (Grieve, 2020) and is a theme that runs throughout the workshop. Being true to oneself when speaking to an audience is crucial, as, no matter how fantastical the setting, the audience enjoys seeing someone react honestly in the moment. When speakers relax and enjoy themselves, the audience does too, so attendees were encouraged to channel their nervousness into excitement (see Brooks, 2014 on the benefits of this) to allow their passion for their subject to infuse their delivery.

\section{Results and feedback}

So far, eight face-to-face workshops have been delivered and the average attendance was 14 people per session, which is higher than the average attendance for researcher support across MRE (approximately nine people per session), and the total number of attendees was 110. We surveyed all those who attended and received 31 responses (a survey response rate of $28 \%$ ). $100 \%$ of those who responded said that they found the session engaging, $90 \%$ said they found it useful and $90 \%$ said they would incorporate what they had learnt into their work. Attendees commented via a post-session survey that the atmosphere in the session was 
'friendly' and 'comfortable' despite the affiliation of public speaking with anxiety; they noted that activities were engaging and useful, and they enjoyed the 'gamification' of networking and the fun approach to tackling nervousness in relation to public speaking. Attendees also reported that working with others on this skill was very valuable to them and that it was useful to 'practise public speaking and to share common fears and issues with other people' (anonymous feedback received through the MRE survey).

I was apprehensive about attending this session, but really enjoyed it in the end [...] Lots of really good practical takeaways, e.g. gamifying networking and breaking presentations down into key sections by reducing the time to summarise. Thank you.

(Anonymous feedback received through the MRE survey)

The above quote is representative of much of the feedback that we received from the attendees. It reflects the feelings of anxiety related to public speaking that the session aimed to address, and it is reassuring that attendees not only had positive experiences of feeling comfortable in the workshop, but that they were also able to identify practical elements that would be of use to them in the future. Although they were initially apprehensive, many attendees fed back that they had enjoyed the session, which indicates that it may have helped them to reframe their worries in relation to public speaking into something more positive. The workshop has also been highly recommended and publicly endorsed by attendees, for example: 'Absolutely brilliant practical advice for public speaking newbies, avoiders, or old hands' (Senior Business Change Manager, Hannah White, taken from Twitter with the author's permission). The popularity of the workshop means that the sessions are regularly oversubscribed; for three of the eight face-to-face sessions we had enough attendees on the waiting list to schedule and fill another workshop straight away (the popularity and over-subscription are factors which have also continued since we moved the workshop online in response to the coronavirus pandemic in March 2020).

In terms of constructive feedback, numerous attendees suggested that the workshop should be longer so that they had time to actually apply some of the techniques, such as those in the exercise 'Say more with less' to their own presentations. The MRE programme and the postsession survey are designed with the view that workshops will always be iterative so that they 
can be adapted to the changing needs of the MRE audience. Feedback is therefore reviewed regularly, and when it is safe to return to face-to-face teaching, this session will be reworked to ensure that attendees have time to apply the techniques to their own work.

\section{Conclusion}

The popularity of the workshop and the feedback received demonstrate the importance and value of using an innovative approach to support researchers to work in community to develop a practical skill in an environment in which they can laugh together if things go wrong. Although this is a reversal of how researchers traditionally experience failure, the stress released through the realisation of their worst fears serves to help them discover techniques to deal with anxiety around public speaking in a cathartic way. Encouraging researchers to support each other means that they can reframe their approach to public speaking together, viewing it not as a source of dread, but as an opportunity to engage in an important dialogue about their ideas. The workshop thereby disrupts negative associations and feelings of anxiety to empower attendees to speak with confidence and authenticity.

The experience of developing and delivering the workshop mirrored many of the fears that our attendees experience in relation to public speaking: nervousness about our unconventional approach, uncertainty about whether the audience would connect with the content, and a certain amount of imposter syndrome in relation to whether the workshop would be accepted as a legitimate form of researcher support. However, both the formal feedback (from the MRE post-session survey) and the informal feedback (of enthusiastic attendees who participated in the sessions and recommended them to others) has demonstrated that the workshop was well received and it is now valued as part of UoM's wider programme of researcher development support.

The next step for the workshop is to adapt the content for online delivery, and this is not without its challenges. Perhaps the greatest challenge concerns how to retain a sense of connection with our attendees whilst being physically distant from one another. We are investigating the use of interactive elements of video conferencing and exercises are being 
adapted so that they are relevant to the 'new normal' in which most talks and conferences will take place online for 2020-2021. A blog post and short video introduction will accompany synchronous (live) sessions delivered via video conferencing to provide asynchronous support for learners in different time zones. The mode of delivery may have changed, but the focus on reframing one's approach to ensure authentic delivery, to build confidence, to engage an audience and to channel positivity when speaking in public will remain the same.

\section{References}

Andrews, J. and Clark, R. (2011) Peer mentoring works! How peer mentoring enhances student success in higher education. Engineering Education Research Group, Aston University. Available at: https://www.heacademy.ac.uk/system/files/aston what works final report 1.pdf (Accessed: 30 Nov 2020).

Barker, L.M. (2018) 'Improvisational theatre in teacher learning about facilitating discussion: exercising pedagogical presence', Action in Teacher Education, 41(1), pp.43-60, https://doi.org/10.1080/01626620.2018.1535460.

Blake, J. R. S., Grayson, N. and Karamalla-Gaiballa, S. (2019) 'Investigating impact: exploring the effect of "open" support on student success', Journal of Learning Development in Higher Education, 0 (16), Available at: https://journal.aldinhe.ac.uk/index.php/jldhe/article/view/540.

Blake, J. and Illingworth, S. (2015) 'Interactive and Interdisciplinary Student Work: A Facilitative Methodology to Encourage Lifelong Learning', Widening Participation and Lifelong Learning, 17(2), pp.108-118, https://doiorg.gate3.library.Ise.ac.uk/10.5456/WPLL.17.2SI.107. 
Boone, D.R. and McFarlane, S.C. (1993) 'A critical view of the yawn-sigh as a voice therapy technique', Journal of Voice, 7(1), pp.75-80, https://doi.org/10.1016/S08921997(05)80114-6.

Boud, D. and Lee, A. (2007) '“Peer learning” as pedagogic discourse for research education', Studies in Higher Education, 30(5), pp.501-516, https://doi.org/10.1080/03075070500249138.

Brooks, A.W. (2014) 'Get excited: Reappraising pre-performance anxiety as excitement', Journal of Experimental Psychology: General, 143(3), pp.1144-1158, DOI: $10.1037 / \mathrm{a} 0035325$.

Daly, J.A., Vangelisti, A.L. and Lawrence, S.G. (1989) 'Self-focused attention and public speaking anxiety', Personality and Individual Differences, 10(8), pp.903-913, https://doi.org/10.1016/0191-8869(89)90025-1.

De Beauvoir, S. (1963). Memoirs of a dutiful daughter. S.L.: Penguin.

Dweck, C.S. (2008) Mindset: the new psychology of success. New York: Ballantine Books.

Evans, T.M., Bira, L., Gastelum, J.B., Weiss, L.T. and Vanderford, N.L. (2018) 'Evidence for a mental health crisis in graduate education', Nature Biotechnology, 36(3), pp.282-284, https://doi.org/10.1038/nbt.4089.

Fisher, D. and Frey, N. (2013) Better learning through structured teaching. Alexandria, Va: ASCD.

Fleming, T.M., Bavin, L., Stasiak, K., Hermansson-Webb, E., Merry, S.N., Cheek, C., Lucassen, M., Lau, H.M., Pollmuller, B. and Hetrick, S. (2017), 'Serious games and gamification for mental health: current status and promising directions', Frontiers in Psychiatry, 7 (215), DOI: 10.3389/fpsyt.2016.00215. 
Grieve, R. (2020) Stand up and be heard: taking the fear out of public speaking at university. London: Sage Publications.

Hattie, J. and Timperley, H. (2007) 'The Power of Feedback', Review of Educational Research, 77(1), pp.81-112, https://doi.org/10.3102/003465430298487.

Johnstone, K. (1979) Impro: improvisation and the theatre; with an introduction by Irving Wardle. New York: Theatre Arts Books.

Kearns, H. (2015) The imposter syndrome: why successful people often feel like frauds. Adelaide, South Australia: Thinkwell.

Nørgård, R.T., Toft-Nielsen, C. and Whitton, N. (2017) 'Playful learning in higher education: developing a signature pedagogy', International Journal of Play, 6(3), pp.272-282, https://doi.org/10.1080/21594937.2017.1382997.

Rubin, R.B., Rubin, A.M. and Jordan, F.F. (1997) 'Effects of instruction on communication apprehension and communication competence', Communication Education, 46(2), pp.104-114, https://doi.org/10.1080/03634529709379080.

Scruggs, M. and Gellman, M.J. (2008) Process: an improviser's journey. Evanston, III.: Northwestern University Press.

The Second City (2020) Reasons to join an improv class. Available at: https://www.secondcity.com/reasons-join-improvclass/\#: :text=Improv\%20classes\%20are\%20a\%20great (Accessed: 27 Nov 2020).

Whitnall, D. and Hurley, U. (2019) 'FAIL LIVE - encouraging failure freedom within PGR communities', Vitae Researcher Development International Conference 2019, Birmingham 16-17 September. 


\section{Author details}

Dr Nicola Grayson is a Learning Developer with expertise in measuring impact and researcher development. She is a Senior Fellow of the Higher Education Academy and works as an Associate Lecturer teaching Philosophy in addition to supporting the design, delivery and evaluation of the University of Manchester Library's learning programmes.

Jessica Napthine-Hodgkinson is a Research Services Officer with expertise in research data management and training development. She is a Fellow of the Association of University Administrators and is an experienced facilitator specialising in applied improvisation within Higher Education. 